\title{
Ligature of External Carotid Artery as an Optional Technique in a Patient with von Willebrand Disease
}

\author{
Leonardo Perez FAVERANI \\ Ellen Cristina GAETTI-JARDIM \\ Gabriel RAMALHO-FERREIRA \\ Jessica Lemos GULINELLI \\ Thallita Pereira QUEIROZ \\ Idelmo Rangel GARCIA JÚNIOR
}

Araçatuba Dental School, UNESP - Univ. Estadual Paulista, Araçatuba, SP, Brazil

\begin{abstract}
The von Willebrand disease (vWD) is a hereditary coagulopathy. There is no gender predilection. Clinically characterized by mucocutaneous bleeding, especially nose bleeding, menorrhagia and bleeding after trauma. This article reports a case of a 52-year-old Caucasian male patient with $\mathrm{vWD}$, who presented with extensive bleeding in the tongue after a lacerating injury caused by accidental biting, and describes some clinical, pathological and treatment aspects of vWD. After repeated attempts to suture the wound and replace clotting factors, a decision was made to perform the ligature of the external carotid artery ipsilateral to the injury. There was favorable resolution of the case, with a good aspect of the scar 2 months after ligation. This case reinforces that it is extremely important to make a thorough review of medical history of all patients, searching for possible bleeding disorders or previous family history.
\end{abstract}

Key Words: von Willebrand disease, von Willebrand factor, hemostasis.

\section{INTRODUCTION}

The von Willebrand disease (vWD) is a hereditary bleeding disorder of vascular or platelet origin, affecting $2 \%$ of the population with no gender predilection, in which there is qualitative or quantitative deficiency of von Willebrand factor (vWF) (1). The vWF is a plasma glycoprotein synthesized by megakaryocytes and endothelial cells which forms binding sites to collagen, platelets and factor VIII coagulation cascade $(2,3,7)$.

Clinically, vWD is manifested by mucocutaneous hemorrhage, characterized by epistaxis, menorrhagia after injuries such as incisions, or lacerating laceration $(1,5)$. The diagnosis of vWD is established after the completion of several exams as bleeding time, coagulation time, platelet count, partial thromboplastin time and factor VIII dosage (10).

In 1999, the National Hemophilia Foundation described the protocol of care for $\mathrm{vWD}$, which consists in administration of cryoprecipitate, a concentrate of blood factors (vWF, FVIII and plasminogen), humate P (which is a purified concentrate of blood factors aimed at excluding the possibility of a viral infection, such as hepatitis and AIDS), and desmopressin, a drug that induces the release of factors VIII and vWF (4).

This paper describes the case of a 52-year-old Caucasian male patient with vWD, who presented with extensive bleeding in the tongue after a lacerating injury, and describes some clinical, pathological and treatment aspects of vWD. External carotid artery ligation is presented as an alternative technique for obtaining hemostasis of wounds in these patients, when conventional measures fail to cease bleeding.

\section{CASE REPORT}

A 52-year-old Caucasian male patient present with bleeding on his tongue after accidental biting. During the clinical interview, the patient reported suffering from VWD type 3 and being under medical treatment for years. He also reported family history of this disease. 
The extraoral clinical examination showed no apparent alteration, but the intraoral examination revealed a lacerated wound in the right lateral border of the tongue causing severe bleeding (Fig. 1).

Hospital admission of the patient was requested. Laboratory tests were run (bleeding time, coagulation time, partial thromboplastin time and hematocrit) and the results showed alterations. The wound was sutured with polyglactin 910 (Johnson \& Johnson Company, São José dos Campos, SP, Brazil) (Fig. 2) and cryoprecipitate was administered by a hematologist.

After the initial intervention, the wound showed no signs of healing until the 13th day, so it was necessary further action in order to perform again the suture and administration of cryoprecipitate concentrate (coagulation factors: FVIII, FIX, von Willebrand factor and fibrinogen) administered intravenously, one unit - 20 $\mathrm{mL}$ every $12 \mathrm{~h}$ for 4 days. Even after the procedures for obtaining hemostasis, bleeding was abundant, with the aggravating factor that every new suture widened the margins of the wound (Fig. 3). Therefore, the choice was made for the excisional biopsy of the lesion. Analysis of the biopsied tissue revealed the presence of an active specific chronic inflammatory process, with no signs of malignancy or specific inflammation. The area was then debrided, cauterized and again sutured with polyglactin 910 (Johnson \& Johnson Company).

After 6 days, synthesis of wound edges with cyanoacrylate was attempted, but it was not successful and the bleeding persisted. Therefore, it was decided to ligate the external carotid artery under general anesthesia, which was performed by vascular surgeons.

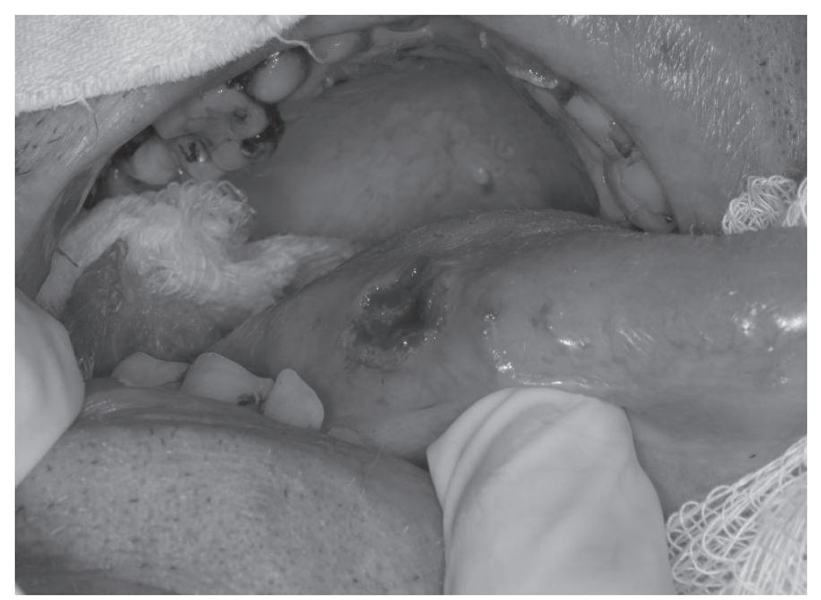

Figure 1. Preoperative inspection of the wound in the lateral border of the tongue.
After debridement of the laceration, suture was made by combination of 4-0 polypropylene (Johnson \& Johnson Company) and polyglactin 910 (Johnson \& Johnson Company) (Fig. 4).

Complete healing with no signs of hemorrhage could be observed 2 months postoperatively (Fig. 5).

\section{DISCUSSION}

Dentist may encounter patients with various conditions in their offices, among which are the coagulopathies, increasing the risk of bleeding both in the pre and postoperative periods (9). In the present case, bleeding was established after the patient had bitted his tongue, causing a lacerated wound with persistent bleeding due to his systemic disease.

As the medical history was reviewed appropriately, revealing type $3 \mathrm{vWD}$ as a preexisting condition, it was possible to establish the appropriated treatment plan for the patient (6).

Treatment of vWD consists in establishing measures to control local hemostasis by means of sutures. In the case of wounds in soft tissues due to injuries, cauterization, application of microfibrillar collagen, and use of cyanoacrylate associated with systemic measures, consisting of blood factor concentrates, such as cryoprecipitate, Humate P or desmopressin are indicated (2).

Humate $\mathrm{P}$ and desmopressin have advantages when compared to cryoprecipitate, since they are purified concentrated coagulation factors and there is no risk of transmission of viral infections, such as AIDS and

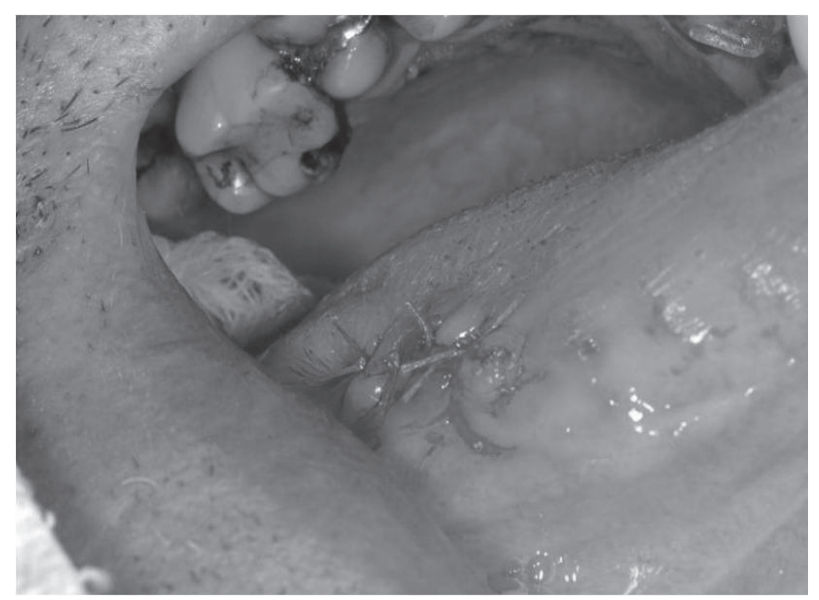

Figure 2. First treatment attempt: suture of the wound with polyglactin 910 . 


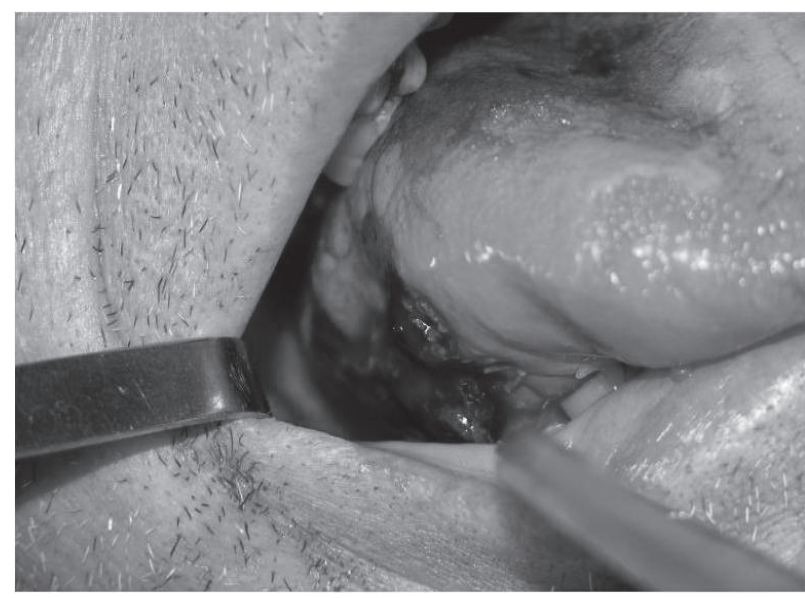

Figure 3. After several attempts to close the laceration, severe bleeding persisted and the new sutures widened more the wound margins.
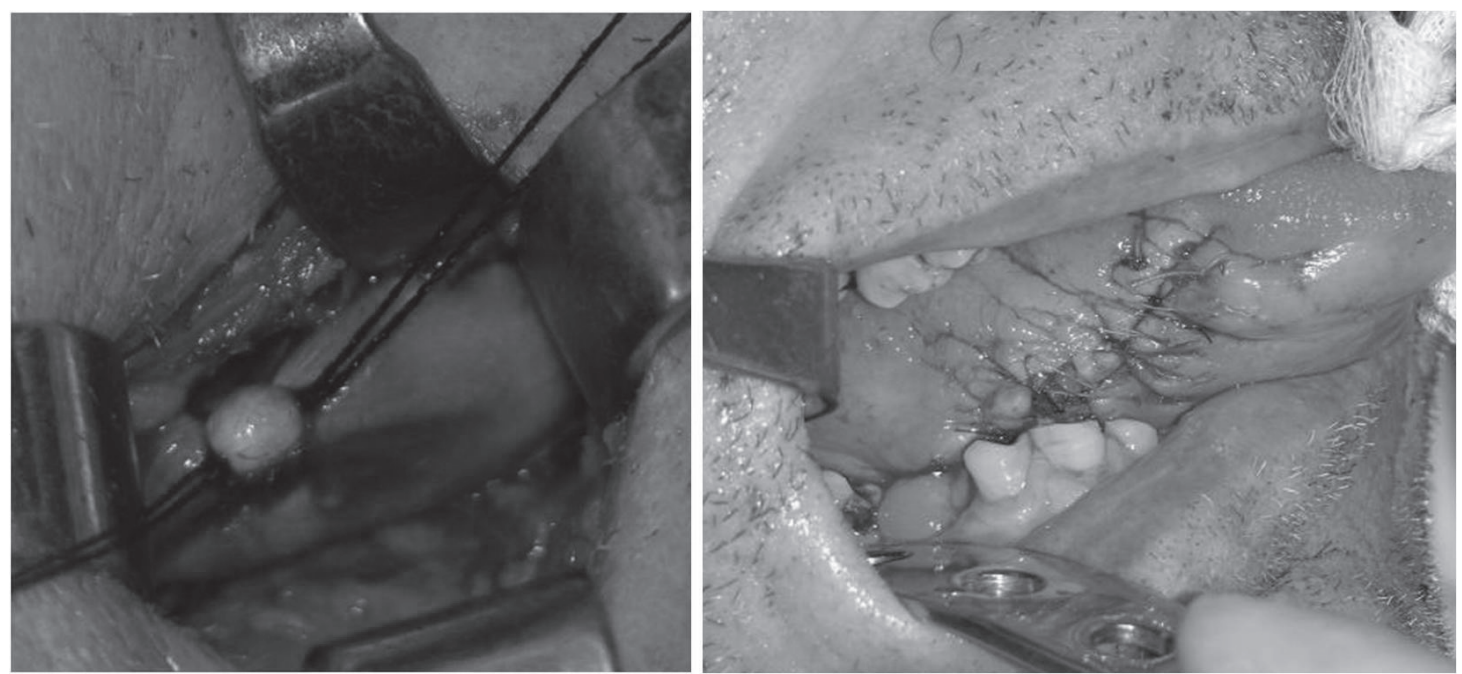

Figure 4. Ligature of the right external carotid artery and suture in layers of the tongue.

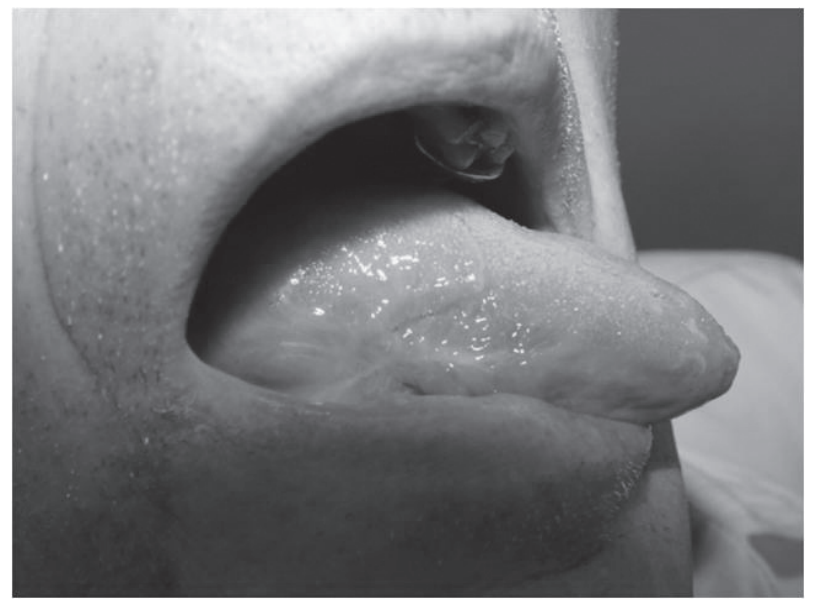

Figure 5. Aspect of the wound 2 months after ligature of the right external carotid artery. 
hepatitis (6).

In the present case, even after administration of cryoprecipitate an intense bleeding was observed, with delay in healing process, leading to necrosis at the edges of the wound. This fact contradicts the literature (6), since the primary control of hemorrhage through sutures was ineffective, which could be related to the fact that tongue has a great range of movement and humidity, making it difficult to maintain the blood clot in a certain position.

Humate $\mathrm{P}$ and desmopressin could have been used as treatment of choice, but these drugs have high cost and the patient could not afford it. So, we opted for clamping a vessel of larger caliber, since all previous attempts at hemostasis were insufficient and ineffective. The target vessel was the external carotid artery on the side corresponding to the injury, since it has the highest blood flow to the entire length of the face.

After artery ligation, there was stabilization of the clot with subsequent wound healing and no more postoperative complications. In summary, it is extremely important to carry out thorough medical history, seeking possible bleeding disorders or previous family history. Furthermore, it is necessary to understand the mechanisms involved in the pathophysiology of the disease, to establish a correct diagnosis and treatment plan.

\section{RESUMO}

A doença de von Willebrand (DvW) é uma coagulopatia hereditária. Não há predileção por sexo. Clinicamente caracterizase por hemorragias mucocutâneas, sobretudo nasais, menorragias e hemorragias pós-trauma. Este artigo relata um caso clínico de DvW em paciente de 52 anos de idade, leucoderma, do sexo masculino, que apresentou extensa hemorragia em bordo lateral de língua após ferimento lacerante, além de descrever alguns aspectos clínicos, patológicos e terapêuticos da DvW. Após repetidas tentativas de sutura do ferimento e reposição dos fatores de coagulação, optou-se pela ligadura da artéria carótida externa ipsilateral ao ferimento, com resolução favorável do caso, notando-se bom aspecto cicatricial 2 meses após a ligadura. Este caso reforça que é de extrema importância a realização de anamnese criteriosa, buscando-se identificar possíveis distúrbios hemorrágicos prévios ou antecedentes familiares.

\section{REFERENCES}

1. Ziebolz D, Stühmer C, Hornecker E, Zapf A, Mausberg RF, Chenot JF. Oral health in adult patients with congenital coagulation disorders - a case control study. Haem 2011;17:527-531.

2. Trigg DE, Stergiotou I, Peitsidis P, Kadir RA. The use of desmopressin for treatment and prophylaxis of bleeding disorders in pregnancy - a systematic review. Haem 2011. [Epub ahead of print. DOI: 10.1111/j.1365-2516.2011.02573.x].

3. Eikenboom J. Linkage analysis in families diagnosed with type 1 von Willebrand disease in the European study molecular and clinical markers for the diagnosis and management of type 1 VWD. J Thromb Haem 2006;4:774-782.

4. Lethagen S. Clinical experience of prophylactic treatment in von Willebrand disease. Thromb Res 2006;118:9-11.

5. Michiels JJ. Characterization, classification, and treatment of von Willebrand diseases: a critical appraisal of the literature and personal experiences. Semin Thromb Hemost 2005;31:577-601.

6. Morimoto Y, Yoshioka A, Sugimoto M, Imar Y, Kirit T. Haemostatic management of intraoral bleeding in patients suffering from von Willebrand disease. Oral Dis 2005;11:243-248.

7. Pasi KJ. Management of von Willebrand disease: a guideline from the UK Haemophilia Centre Doctors' Organization. Haem 2004; 10:218-231.

8. Perutelli P, Biglin P, Mori R. von Willebrand factor: Biological functions and molecular defects. Ped Hematol Oncol 1997;14:499552.

9. Prochorec-Sobieszek M, Windyga J, Maryniak RK, Misiak A, Szczepanik A. Angiodysplasia as a cause of recurrent bleeding from the small bowel in patients suffering from von Willebrand disease. Report of four patients. Pol J Pathol 2004;55:173-176.

10. Veyradier A, Fressinaud E, Meyer D. Laboratory diagnosis of von Willebrand disease. Int J Clin Lab Res 1998;28:201-210.

Received February 13, 2011

Accepted June 30, 2011 